\title{
Production and characterisation of monoclonal antibodies against immunoglobulins of Cirrhinus mrigala (Hamilton 1822)
}

\author{
SNATASHREE MOHANTY ${ }^{1}$, M. MAKESH ${ }^{2}$, K.V. RAJENDRAN ${ }^{3}$, P. P. SURESH BABU ${ }^{4}$, DEEPIKA \\ ANAND $^{3}$, SAURAV KUMAR ${ }^{3}$, ABHAY KUMAR $^{5}$, RAJU BAITHA ${ }^{6}$ AND KAMAL SARMA ${ }^{7}$ \\ ${ }^{1}$ ICAR-Central Institute of Freshwater Aquaculture, Bhubaneswar - 751 002, Odisha, India \\ ${ }^{2}$ ICAR-Central Institute of Brackishwater Aquaculture, Raja Annamalai Puram, Chennai - 600 028, Tamil Nadu, India \\ ${ }^{3}$ ICAR-Central Institute of Fisheries Education, Mumbai - 400 061, Maharashtra, India \\ ${ }^{4}$ Karwar Research Centre of ICAR-Central Marine Fisheries Research Institute, Karwar - 581 301, Karnataka, India \\ ${ }^{5}$ ICAR-Central Institute of Fisheries Technology, Willingdon Island, Kochi - 682 029, Kerala, India \\ ${ }^{6}$ ICAR-Central Inland Fisheries Research Institute, Barrackpore, Kolkata - 700 120, West Bengal, India \\ ${ }^{7}$ ICAR-Research Complex for Eastern Region, Patna - 800 014, Bihar, India \\ e-mail: snatashree.m@gmail.com
}

\begin{abstract}
Serum immunoglobulins (Ig) of mrigal Cirrhinus mrigala (Hamilton 1822) immunised with bovine serum albumin (BSA), were purified by affinity chromatography using BSA-CL agarose column. The purified mrigal Ig (m-Ig) was characterised under reducing condition by Sodium Dodecyl Sulphate Polyacrylamide Gel Electrophoresis (SDS-PAGE) which revealed two bands of 85 and $26 \mathrm{kDa}$ corresponding to heavy and light chain, respectively. Following fusion of splenocytes from $\mathrm{Balb} / \mathrm{c}$ mice immunised with purified $\mathrm{m}$-Ig with myeloma cells, three hybridomas showing reactivity with $\mathrm{m}$-Ig were cloned by limiting dilution. The monoclonal antibodies (MAbs) generated by these clones were designated as 3B2-E12, 3B2-F9 and $4 \mathrm{C} 3-\mathrm{B} 2$ and characterised by western blotting and isotyping. Western blot analysis of the supernatant from the three clones with purified $\mathrm{m}$-Ig indicated that, all the three MAbs were specific to heavy chain. Isotyping revealed that 3B2-E12 $\mathrm{MAb}$ was of IgG1 isotype whereas the other two MAbs were of IgG2a isotype. Cross reactivity of anti-mrigal Ig MAb (3B2-E12) was observed with serum Ig of Catla catla and Labeo rohita indicating semi-conserved nature of Ig in Indian major carps.
\end{abstract}

Keywords: Cirrhinus mrigala, ELISA, Immunoglobulin, Monoclonal Antibodies, Western blotting

\section{Introduction}

Teleosts are the earliest vertebrates to possess both innate and adaptive immunity. The innate or non-specific immune parameters are the frontline fighters, first to respond to pathogens whereas the adaptive immune system armed with specificity and memory is acquired with time and provides extended immunity. Adaptive immunity in teleosts comprises both humoral and cell mediated immunity (Sood et al., 2012). The immunoglobulins secreted by $B$ cells play an important role in humoral immunity. Out of the three different $\operatorname{Ig}$ isotypes i.e. $\operatorname{IgM}, \operatorname{IgD}$ and $\operatorname{IgT}, \operatorname{IgM}$ is considered as the primary humoral component in most of the teleost fish (Bag et al., 2009). The mrigal Cirrhinus mrigala (Hamilton1822), is an Indian major carp (IMC) species endemic to Indo-Gangetic riverine systems. Owing to its consumer preference, the species forms an integral part of carp polyculture system. However, due to its bottom dwelling habit, the species faces increased risk of susceptibility to bacterial pathogens which is reported to be
10-20 times higher as compared to those species dwelling in the water column (Lewis and Bender, 1961). In addition, with regard to one of the serious oomycete fish pathogen Aphanomyces invadans. causing epizootic ulcerative syndrome in both freshwater and estuarine fishes, C. mrigala is reported to be severely affected in comparison to other species of IMCs (Parvati et al., 2011; Pradhan et al., 2014).

Monoclonal antibodies (MAbs) against Ig provide a powerful tool for monitoring the level of total and specific antibody production (Tang et al., 2010) following an infection or vaccination (Al-Harbi, et al., 2000). To date, MAbs have been established for a variety of freshwater and marine fish species. These include Ictalurus punctatus (Edholm et al., 2010), Paralichthys olivaceus (Li et al., 2007), Takifugu rubripes (Miyadai et al., 2004), Labeo rohita (Rathore et al., 2008), Channa striata (Sood et al., 2011), Clupea pallasii (Purcell et al., 2012), Clarias batrachus (Sood et al., 2012), Labeo rohita (Rebello et al., 2016), Lateolabrax japonicas (Yang et al., 
2018), Oncorhynchus mykiss (Hayashi et al., 2019) and Carassius auratus gibelio (Wu et al., 2020). All of these MAbs developed have numerous diagnostic applications in fish health management. With regard to mrigal, there has been report of isolation and characterisation of serum IgM (Bag et al., 2009) but, MAbs against the Ig of mrigal have not yet been developed. Therefore, the present study was planned to purify serum Ig of C. mrigala, to produce MAbs against the purified Ig and to characterise the MAbs. It is envisaged that, MAbs against serum Ig of C. mrigala will help in better understanding of the immune system of the species and will act as a source of diagnostic reagent in MAb based immunoassays.

\section{Material and methods}

\section{Immunisation of C. mrigala}

Apparently healthy specimens of $C$. mrigala $(\mathrm{N}=7$, $255 \pm 30 \mathrm{~g}$ ) were collected from the freshwater fish farm of the Researh Centre of ICAR-Central Institute of Fisheries Education (ICAR-CIFE) at Balbhadrapuram, Andhra Pradesh, India. After acclimatisation for two weeks, fish were immunised intraperitoneally with $200 \mu \mathrm{g}$ bovine serum albumin (BSA) emulsified with Freund's Complete Adjuvant (FCA) (GeNei, India) @ $0.2 \mathrm{ml} 100 \mathrm{~g}^{-1}$ body weight and subsequently boosted thrice with similar emulsion in Freund's Incomplete Adjuvant (FIA) (GeNei, India) at two weeks interval. Post-immunisation (7 days after final dose), blood samples were collected and allowed to clot overnight at $4^{\circ} \mathrm{C}$. The clotted blood was centrifuged@5000 g to separate serum and the serum collected was stored at $-20^{\circ} \mathrm{C}$ for further studies.

\section{Purification of mrigal Ig by affinity chromatography}

Mrigal Ig was purifed using an immuno-affinity BSACL Agarose column (GeNei, India) following Swain et al. (2004). The serum was diluted @ 1:3 with Tris buffered saline (TBS: $0.02 \mathrm{M}$ Tris-HCl, $0.15 \mathrm{M} \mathrm{NaCl}, \mathrm{pH} 7.4$ ), filtered through $0.45 \mu \mathrm{m}$ syringe filter and passed through affinity column. Before loading the samples, the column was washed with five-bed volumes $(25 \mathrm{ml})$ of washing buffer (TBS) and then stripped with four-bed volumes (20 ml) of elution buffer (0.1 M glycine $\mathrm{NaOH}, \mathrm{pH} 11.0$ ) followed by washing with ten-bed volumes $(50 \mathrm{ml})$ of TBS. The serum was loaded to the column slowly and the flow-through was repeatedly added to the column for efficient binding of the Igs to the column. The column was washed with TBS till the absorbance of the flow-through at $280 \mathrm{~nm}$ wavelength, became same as that of TBS. After washing of column, bound Ig in the column was eluted with $10 \mathrm{ml}$ of elution buffer (0.1 M glycine, $\mathrm{pH} 11.0)$ and the filtrate was collected in $1.5 \mathrm{ml}$ Eppendorf tubes. The absorbance of the fractions was measured at $280 \mathrm{~nm}$ using a spectrophotometer (Thermo Spectronic, USA). The fractions showing $>0.1$ OD were pooled together followed by concentration in a cellulose membrane dialysis tubing (Sigma, USA). Subsequently, SDS-PAGE was carried out to check the purity and molecular weight (MW) of the purified Ig.

Characterisation of mrigal Ig (m-Ig): Sodium dodecyl sulphate polyacrylamide gel electrophoresis (SDS-PAGE)

The affinity purified Ig was characterised using SDS-PAGE, following the standard protocol of Botwell and Sambrook (2002). SDS-PAGE was carried out on a $7.5 \mathrm{~cm} \times 8.5 \mathrm{~cm}$ polyacrylamide gel of $1 \mathrm{~mm}$ thickness in a vertical gel electrophoresis apparatus (Technosource, India). The concentration of separating gel and stacking gel were 12 and 5\%, respectively. Following electrophoresis, the gel was stained with $0.25 \%$ coomassie brilliant blue R-250 and analysed in gel documentation system (DNr Bioimaging System, Israel).

\section{Production of anti-mrigal Ig antibodies in mice}

Female Balb/c mice, eight weeks old, were procured from the Advanced Centre for Treatment, Research and Education in Cancer (ACTREC), Kharghar, Navi Mumbai with the authentic permission and approval of Institutional Animal Ethics Committee, ICAR-CIFE, Mumbai. Two numbers of Balb/C mice were immunised intraperitoneally with $50 \mu \mathrm{g}$ of $\mathrm{m}-\mathrm{Ig}$ emulsified in FCA. The mice were boosted similarly with $\mathrm{m}-\mathrm{Ig}$ emulsified with FIA on $14^{\text {th }}$ and $28^{\text {th }}$ day of first immunisation. On $36^{\text {th }}$ day, mice were injected with $50 \mu \mathrm{g}$ of purified $\mathrm{m}-\mathrm{Ig}$ intravenously. After three days, the mice were anaesthetised using diethyl ether and bled for testing immune response. Serum was separated by centrifugation of clotted blood at $5000 \mathrm{~g}$ for $10 \mathrm{~min}$ and stored at $-20^{\circ} \mathrm{C}$ for further use.

\section{Immune response in mrigal and mice}

Analysis of anti-BSA antibody in the affinity purified serum by Western blotting

Five microliters of BSA $\left(1 \mathrm{mg} \mathrm{ml}^{-1}\right)$ was subjected to SDS-PAGE in three lanes along with a protein molecular weight marker on a $10 \%$ polyacrylamide gel. The gel was run initially at $70 \mathrm{~V}$ till the tracking dye reached the separating gel and the voltage was subsequently increased to $110 \mathrm{~V}$ till the dye reached bottom of the gel. The lane in the gel having molecular weight marker was transferred to $0.25 \%$ coomassie brilliant blue R-250 staining solution. The image of stained gel was analysed in Gel documentation system (DNr, Bio-imaging system, Israel). The remaining gel was used for western blotting. The unstained gel was transferred to Poly Vinylidene Difluoride (PVDF) membrane at constant current of $350 \mathrm{~mA}$ for $1.5 \mathrm{~h}$, followed by blocking in PBS with $5 \%$ skimmed milk powder for $1 \mathrm{~h}$ at room temperature 
(RT) and subsequently incubated with serum collected from immunised mrigal diluted at 1:1000 in PBST (PBS with $0.05 \%$ Tween-20) for $1 \mathrm{~h}$ at RT. The membrane was then incubated with mouse anti-mrigal Ig serum (diluted at 1:2000 with PBST) for $1 \mathrm{~h}$ at RT, followed by incubation with goat anti-mouse HRP conjugate (1:1000) (GeNei, India) for $1 \mathrm{~h}$ at RT. The membrane was incubated with substrate solution containing $10 \mathrm{mg}$ of diaminobenzidine (DAB) in $30 \mathrm{ml}$ of PBS having $10 \mu \mathrm{l}$ of hydrogen peroxide, for $10 \mathrm{~min}$ in dark. The membrane was then washed in tap water, air-dried and analysed.

Production of monoclonal antibodies (MAbs) against mrigal Ig

MAbs against $\mathrm{m}$-Ig were raised as per Hamilton and Davis (1995). Briefly, female BALB/c mice immunised with affinity purified $\mathrm{m}$-Ig, were sacrificed five days after third booster injection and the spleen was collected under aseptic conditions. Spleen cells were fused with myeloma (SP2/0) cells in logarithmic phase, at a ratio of 10:1 using sterile polyethylene glycol (PEG) (Hybrimax, Sigma, USA), as fusion agent. The fused cells were grown in DMEM with 20\% fetal bovine serum (FBS) and HAT (Hypoxanthine-Aminopterin-Thymidine) supplement. The cells were seeded in 96 well tissue culture plates containing feeder cells for nourishment @ $100 \mu \mathrm{l}$ per well and incubated in $\mathrm{CO}_{2}$ incubator. Feeder cells were prepared two days prior to fusion by collecting macrophages and spleen cells from mice and suitably diluted in DMEM along with $20 \%$ FBS so as to get a concentration of $10^{5}$ cells per well and seeded in 96 well tissue culture plates @ $100 \mu \mathrm{l}$ per well followed by incubation for two days at $37^{\circ} \mathrm{C}$ with $5 \% \mathrm{CO}_{2}$ in incubator. The plates were observed regularly for growth of hybridomas and positive clones were screened by indirect ELISA. Positive hybridomas were expanded, followed by sub-cloning by limiting dilution method. Single clones were again screened for antibodies to mrigal Ig by indirect ELISA. Subsequently, the selected clones were characterised by western blotting and isotyping.

\section{Screening of hybridomas by indirect ELISA}

ELISA plate was coated with $100 \mu 1$ of purified m-Ig (5 ng $\mu \mathrm{l}^{-1}$ ) in coating buffer. The plate was incubated overnight at $4^{\circ} \mathrm{C}$, washed thrice with PBST and blocked with $3 \%$ BSA in PBS at RT for $1 \mathrm{~h}$. Thereafter, $100 \mu \mathrm{l}$ of the hybridoma culture supernatant was added and incubated for $90 \mathrm{~min}$ at RT. Supernatant from SP2/0 myeloma cells served as negative control. Mouse serum from immunised mice at a dilution of 1:1000 was used as positive control. Mouse serum from immunised mice at a dilution of 1:1000 was used as positive control. The wells were washed with PBST followed by incubation with anti-mouse IgG HRP conjugate (Sigma, 1:2000 dilution in PBST) for $1 \mathrm{~h}$ at RT. Subsequently, $100 \mu \mathrm{l}$ of the substrate solution containing ABTS (2, 2'-Azinobis [3-ethylbenzothiazoline-6-sulfonic acid]-diammonium salt) in sodium citrate buffer having $0.1 \% \mathrm{H}_{2} \mathrm{O}_{2}$ was added to the wells. After incubation for $10 \mathrm{~min}$ in dark, plate was read at $405 \mathrm{~nm}$ in ELISA plate reader (BioTek Power Wave 340, USA).

\section{MAbs characterisation by Western blotting}

Selected MAbs were characterised to determine the reactivity of the anti-mrigal Ig MAbs to reduced mrigal Ig following standard procedure as mentioned earlier.

Isotyping

Class and subclass of mouse Ig produced by hybridomas were determined by capture ELISA, using mouse monoclonal antibody isotyping kit (Sigma, USA) as per instructions of the manufacturer.

\section{Cross reactivity of MAbs}

The cross reactivity of anti-mrigal Ig MAbs with serum of L. rohita and Catla catla was checked employing western blotting. The serum of $C$. catla and L. rohita was run in 3 wells each in a SDS-PAGE gel and transferred to a PVDF membrane. The PVDF membrane was incubated with culture supernatant from each of the three clones for $1.5 \mathrm{~h}$ at RT. After washing and subsequent incubation with anti-mouse IgG-HRP conjugate and substrate, the membrane was washed with tap water and air dried (as mentioned earlier) and analysed.

\section{Results and discussion}

In the present study, an affinity column of $4 \%$ agarose beads coupled with BSA was used to purify Ig from mrigal hyper-immune serum. The anti-BSA antibodies were successfully eluted using BSA-CL agarose affinity column in accordance with previous reports in Atlantic salmon (Pettersen et al., 2000); Asian catfish (Swain etal., 2004); IMCs (Bag etal., 2009) and C. batrachus (Sood et al., 2012). Further, in this study, about $7.24 \mathrm{mg}$ of $\mathrm{Ig}$ was recovered from total $10 \mathrm{ml}$ of immunised mrigal serum@0.72 mg ml-1 of mrigal serum. The yield of $\mathrm{m}-\mathrm{Ig}$ in this study was higher than that reported in Asian catfish, $0.15 \mathrm{mg} \mathrm{ml}^{-1}$ (Swain et al., 2004); Southern blue fin tuna, 0.16-0.3 $\mathrm{mg} \mathrm{ml}^{-1}$ (Watts et al., 2001); IMCs, $0.315,0.33$ and $0.255 \mathrm{mg} \mathrm{ml}^{-1}$ for catla, rohu and mrigal, respectively (Bag et al., 2009) and magur, $0.275 \mathrm{mg} \mathrm{ml}^{-1}$ (Sood et al., 2012). However, it was lower as compared to that reported in snapper, $0.85-1.47 \mathrm{mg} \mathrm{ml}^{-1}$ (Morrison and Nowak, 2001) and seabass, $1 \mathrm{mg} \mathrm{ml}^{-1}$ (Palenzuela et al., 1996). The yield of immunoglobulins depends on size and age of fish as well as environment (Zilberg and Klesius, 1997). 
The affinity purified $\mathrm{m}-\mathrm{Ig}$ in SDS-PAGE revealed two bands of $85 \mathrm{kDa}$ and $26 \mathrm{kDa}$ which corresponded to heavy chain (HC) and light chain (LC), respectively (Fig. 1). Previously, Suresh et al. (2008) reported HC and LC of affinity purified rohu Ig as $85 \mathrm{kDa}$ and $23 \mathrm{kDa}$ bands, respectively. In agreement with our results, Bag et al. (2009) reported HC and LC for catla, rohu and mrigal Ig to be 88 and $26 \mathrm{kDa}$ respectively. The molecular weight of $\mathrm{H}$ chain in tilapia has also been reported to be $90 \mathrm{kDa}$ (Rajavarthini et al., 2000) and $86 \mathrm{kDa}$ in barramundi (Crosbie and Nowak, 2002). Single heavy and light chains, as observed in the present study, were also reported in Japanese eel (Uchida et al., 2000), common carp (Vesely et al., 2006), seabass (Scapigliati et al., 1996), gilthead seabream (Palenzuela et al., 1996), L. rohita (Rathore et al., 2008) and Clupea pallasii (Purcell et al., 2012). Western blotting of BSA with immunised fish serum and mouse anti-mrigal Ig showed a specific band at $66 \mathrm{kDa}$. This clearly indicated specific immune response in fish against BSA and in mice against m-Ig (Fig. 2).

Hybridomas producing MAbs against m-Ig were cloned on the basis of results of indirect ELISA. The wells with hybridoma culture supernatant having significantly higher OD $(>0.500)$ compared to negative control were considered positive and chosen for further expansion. Subsequently, three stable hybridomas were cloned by limiting dilution and designated as 3B2-E12, 3B2-F9 and 4C3-B2 which were further characterised. The heavy chain isotypes of these three MAbs were determined to be IgG1, IgG2a and IgG2a, respectively. To authors' knowledge, this is the first report of development of MAbs specific to mrigal Ig. All of the MAbs, reacted strongly with the HC of mrigal Ig and no reactivity was observed with the LC. Previous studies indicated that $\mathrm{HC}$ is more antigenic in nature as compared to LC, as most of the MAbs against fish Ig are specific for the $\mathrm{HC}$ of Ig (Scapigliati et al.,

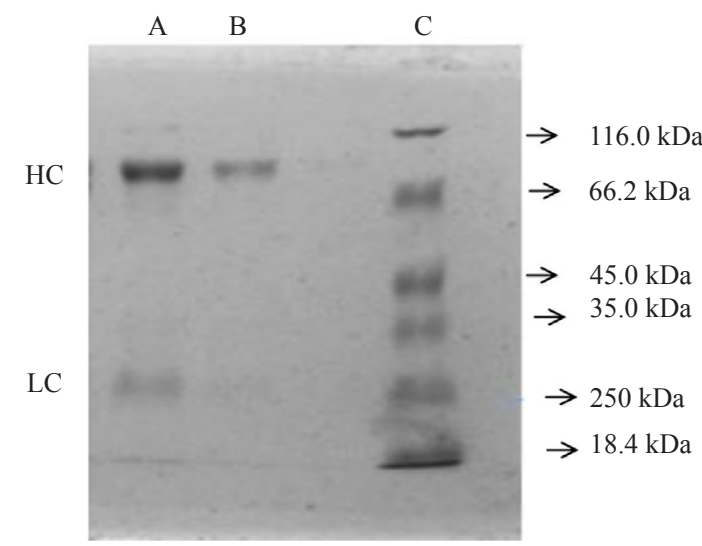

Fig. 1. SDS-PAGE gel image of purified anti-BSA Ig from C. mrigala.

Lane A and B: Mrigal Ig; Lane C: Molecular weight marker; HC: Ig Heavy chain; LC: Ig Light chain
1999). The present findings of specific reaction of MAbs to $\mathrm{HC}$ corroborates with earlier studies in Oreochromis niloticus (Al-Harbi et al., 2000); Paralichthys olivaceous (Jang et al., 2004; Li et al., 2007); Sebastes schlegeli (Shin et al., 2006) Pagrus auratus (Morrison et al., 2002); Takifugu rubripes (Miyadai et al., 2004); common carp (Vesely et al., 2006); L. rohita (Rathore et al., 2008; Suresh et al., 2014); C. pallasii (Purcell et al., 2012) and C. batrachus (Sood et al., 2012). Class and subclass of MAbs developed in this study were determined using a capture ELISA-based mouse Ig isotyping kit, which revealed that 3B2-E12 MAb is of isotype IgG1 whereas, 3B2-F9 and 4C3-B2 MAbs are of isotype IgG2a. Out of the seven anti-O. niloticus MAbs developed by Al-Harbi et al. (2000), four were of IgG2b, two were IgG2a and one was IgG3. Two anti-rohu Ig MAbs developed by Rathore et al. (2008) belonged to subclass IgG2b and IgG1.

The MAbs designated as 3B2-F9, 3B2-E12 and 4C3-B2 showed specific reaction with the heavy chain of purified m-Ig at molecular weight of $85 \mathrm{kDa}$ (Fig. 3). Antigenic relatedness of $\mathrm{m}-\mathrm{Ig}$ with serum Ig of other IMCs, namely catla and rohu, was demonstrated by the cross reactivity pattern of MAbs with serum of C. catla and L. rohita. After immunoblotting, it was found that MAbs (3B2-E12) showed specific reaction with serum of mrigal, rohu and catla at the position of $\mathrm{HC}$, suggesting cross-reactivity of developed MAbs to serum of phylogenetically related species in the same family (Fig. 4). Our results reveal that the epitope of mrigal Ig recognised by MAbs is shared with catla and rohu Ig. The antigenic relatedness of fish Ig within species of the same family, as shown by MAbs binding in the present study, has previously been reported for puffer fish (Miyadai et al., 2004), rohu (Rathore et al., 2008) and magur (Sood et al., 2012).

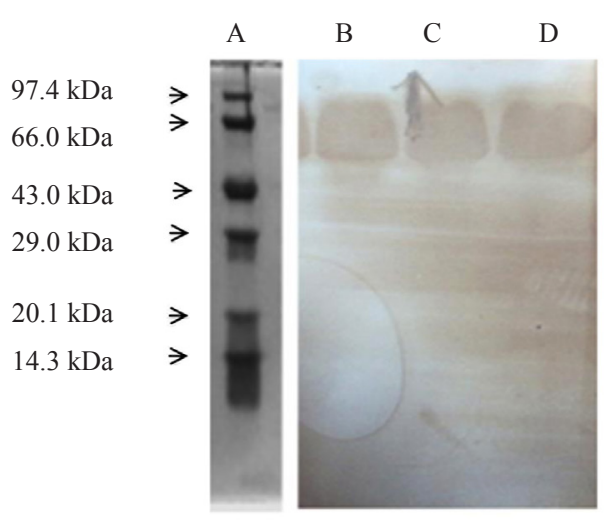

Fig. 2. Western blot image of antiserum from C. mrigala directed against BSA

Lane A: Stained molecular weight marker; Lane B, C and D: BSA western blotted with anti-mrigal Ig serum 


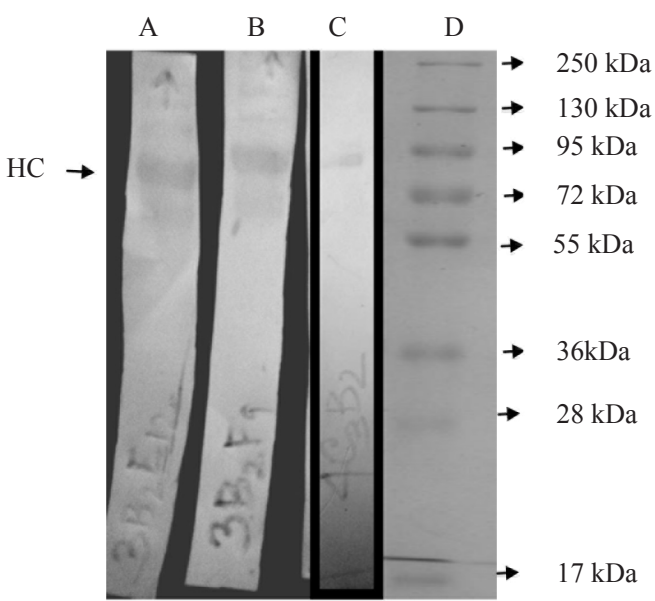

Fig. 3. Western blot image of anti-mrigal Ig MAbs Lane A, B and C: Immunoblot of purified mrigal Ig with anti-mrigal Ig MAbs; Lane D: Molecular weight marker

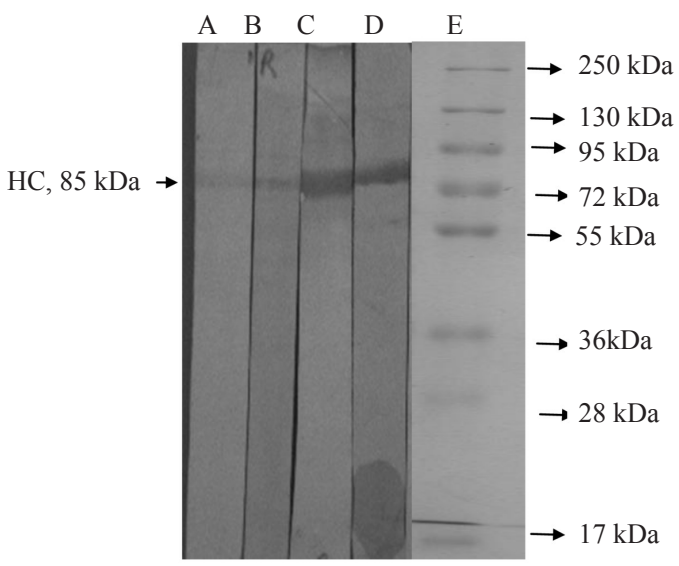

Fig. 4. Antigenic relatednes of mrigal Ig MAb to catla and rohu serum Ig

Lane A: Immunoblot of catla serum with anti-mrigal Ig MAb (3B2-E12); Lane B: Immunoblot of rohu serum with anti-mrigal Ig MAb; Lane C: Immunoblot of mrigal serum with anti-mrigal Ig MAb; Lane D: Immunoblot of mrigal Ig with anti-mrigal Ig MAb; Lane E: Molecular weight marker

It is concluded that the affinity purified mrigal $\mathrm{Ig}$ comprised single $\mathrm{HC}$ and LC and the produced MAbs were specific for $\mathrm{m}-\mathrm{Ig} \mathrm{HC}$. These can be effectively utilised for sero-monitoring of pathogens in mrigal. Since one of the $\mathrm{MAb}$ cross reacted with catla and rohu Ig, it can be used to monitor the immune response in these species following infection and vaccination. The anti-mrigal Ig MAbs will have applications in developing antibody-based assays that can be successfully employed in disease diagnosis for effective fish health management.

\section{Acknowledgements}

The authors wish to acknowledge the Director, ICAR-CIFE, Mumbai, India, for providing all the facilities required to successfully carry out the study.

\section{References}

Al-Harbi, H., Trux, R. and Thune, R. L. 2000. Production and characterization of monoclonal antibodies against tilapia, Oreochromis niloticus immunoglobulin. Aquaculture, 188: 219-227. doi.org/10. 1016/S0044-8486(00)00347-1.

Bag, R. M., Makesh, M., Rajendran, K. V. and Mukherjee, S. C. 2009. Characterisation of IgM of Indian major carps and their cross reactivity with anti-fish IgM antibodies. Fish Shellfish Immunol., 26: 275-278. doi: 10.1016/j. fsi.2008.11.009.

Banu, H., Anand, D., Bedekar, M. K., Rajendran, K. V. and Makesh, M. 2017. Monoclonal antibodies against recombinant GAPDH of Edwardsiella tarda reveal the conserved nature of the protein. Food Agric. Immunol., 4: 685-698. https://doi.org/10.1080/09540105.2017.1309642.

Botwell, D. and Sambrook, J. 2002. DNA microarrays: a molecular cloning manual. Cold spring Harbor Laboratory Am. J. Hum. Genet., 73: 218-219.

Crosbie, P. B. B. and Nowak, B. F. 2002. Production of polyclonal antisera against barramundi (Lates calcarifer Bloch) serum immunoglobulin derived from affinity columns containing mannan binding protein or staphylococcal protein A. Aquaculture, 211: 49-63. DOI: 10.1016/S00448486(02)00136-9.

Edholm, E., Hudgens, E. D., Tompkins, D., Sahoo, M., Burkhalter, B., Miller, N. W., Bengten, E. and Wilson, M. 2010. Characterization of anti-channel catfish $\operatorname{IgL} \sigma$ monoclonal antibodies. Vet. Immunol. Immunopathol., 135(34): 325-328

Hamilton, M. J. and Davis, C. W. 1995. Culture conditions that optimise outgrowth of hybridomas. In: Davis, C.W. (Ed.), Monoclonal antibody protocols. Humana Press, Totawa, New Jersey, USA, p. 17-26.

Hayashi, M., Ichida, K., Sadaie, S., Miwa, M., Fujihara, R., Nagasaka, Y. and Yoshizaki, G. 2019. Establishment of novel monoclonal antibodies for identification of type A spermatogonia in teleosts. Biol. Reprod., 0(0): 1-14.

Jang, H. N., Woo, J. K., Cho, Y., Kyong, S. B. and Choi, S. H. 2004. Characterisation of monoclonal antibodies against heavy and light chain of flounder Paralichthys olivaceous immunoglobulin. J. Biochem. Mol. Biol., 37: 314-319. doi: 10.5483/bmbrep.2004.37.3.314.

Lewis, W. M. and Bender, M. 1961. Free-living ability of a warm water fish pathogen of the genus Aeromonas hydrophila-standardisation of dose and duration for oral vaccination of carps. Fish Shellfish Immunol., 9: 519-528.

Li, Q., Zhan, W., Xing, J. and Sheng, X. 2007. Production, characterisation and applicability of monoclonal antibodies 
to immunoglobulin of Japanese flounder (Paralichthys olivaceus). Fish Shellfish Immunol., 23: 982-990.

Miyadai, T., Ootani, M., Tahara, D., Aoki, M. and Saitoh, K. 2004. Monoclonal antibodies recognising serum immunoglobulins and surface immunoglobulin-positive cells of puffer fish, torafugu (Takifugu rubripes). Fish Shellfish Immunol., 17: 211-222. doi: 10.1016/j. fsi.2004.03.005.

Morrison, R. N. and Nowak, B. F. 2001. Affinity purification and partial characterisation of systemic immunoglobulin of snapper (Pagrus auratus). Aquaculture, 201: 1-17. DOI: 10.1016/S0044-8486(01)00566-X.

Morrison, R. N., Hayball, J. D., Cook, M. T. and Nowak, B. F. 2002. Anti-immunoglobulin binding and activation of snapper (Pagrus auratus) leucocytes. Dev. Comp. Immunol., 26: $247-255$.

Palenzuela, O., Sitja-Bobadila, A. and Alvarez-Pellitero, P. 1996. Isolation and partial characterisation of serum immunoglobulins from seabass, (Dicentrarchus labrax L.) and gilthead seabream, (Sparus aurata L.). Fish Shellfish Immunol., 6: 81-94.

Parvati, S., Sihag, R. C. and Anuradha B. 2011. Seasonal incidences of hemorrhagic septicemia and epizootic ulcerative syndrome in mrigal (Cirrhinus mrigala L.) in different fish farms around Hisar, Haryana. Trends Biosci., $4: 215-218$

Pettersen, E. F., Bjerknes, R. and Wergeland, H. I. 2000. Studies of Atlantic salmon (Salmo salar L.) blood, spleen and head kidney leucocytes using specific monoclonal antibodies, immunohistochemistry and flow cytometry. Fish Shellfish Immunol., 10: 695-710. doi: 10.1006/fsim.2000.0284.

Pradhan, P. K., Rathore G., Sood, N., Swaminathan, T. R., Yadav, M. K., Verma, D. K., Chaudhary, Abidi R., Punia, P. and Jena, J. K. 2014. Emergence of epizootic ulcerative syndrome: large-scale mortalities of cultured and wild fish species in Uttar Pradesh, India. 2014. Curr. Sci., 106: 12-25.

Purcell, M. K., Bromage, E. S., Silva, J., Hansen, J. D., Badil, S. M., Woodson, J. C. and Hershberger, P. K. 2012. Production and characterisation of monoclonal antibodies to $\operatorname{IgM}$ of Pacific herring (Clupea pallasii). Fish Shellfish Immunol., 33: 552-558. doi: 10.1016/j.fsi.2012.06.006.

Rajavarthini, P. B., Amukumar, R. I. and Michael, R. D. 2000. Partial characterization of serum immunoglobulin of Oreochromis mossambicus. Indian J. Exp. Biol., 38: 549-553.

Rathore, G., Kumar, G., Sood, N., Kapoor, D. and Lakra, W. S. 2008. Development of monoclonal antibodies to rohu, Labeo rohita immunoglobulins for use in immunoassays. Fish Shellfish Immunol., 25: 761-774. DOI: 10.1016/j. fsi.2008.02.014.

Rebello, S. C., Rathore, G., Punia, P. and Sood, N. 2016. Development and characterization of a monoclonal antibody against the putative $\mathrm{T}$ cells of Labeo rohita.
Cytotechnology, 68: 469-480. doi: 10.1007/s10616-0149800-6.

Salinas, I., Zhang, Y. A. and Sunyer, J. O. 2011. Mucosal immunoglobulins and B cells of teleost fish. Dev. Comp. Immunol., 35: 1346-1365. doi: 10.1016/j.dci.2011.11.009

Scapigliati,G.,Romano,N.,Picchietti,S.,Mazzini,M.,Mastrolia,L. and Scalia, D. 1996. Monoclonal antibodies against seabass Dicentrarchus labrax (L.) immunoglobulins: immunolocalisation of immunoglobulin-bearing cells and applicability in immunoassays. Fish Shellfish Immunol., 6: 383-401. https://doi.org/10.1006/fsim.1996.0038.

Scapigliati, G., Romano, N. and Abelli, L. 1999. Monoclonal antibodies in fish immunology: identification, ontogeny and activity of T and B-lymphocytes. Aquaculture, 172: 3-28. https://doi.org/10.1016/S0044-8486(98)00440-2.

Shin, G., Lee, H., Palaksha, K. J., Kin, Y., Lee, E., Shin, Y., Lee, E., Park, K. and Jung, T. 2006. Production of monoclonal antibodies against serum immunoglobulins of black rockfish (Sebastes schlegeli Higendorf). J. Vet. Sci., 7: 293-295.

Sood, N., Chaudhary, D. K., Rathore, G., Singh, A. and Lakra, W. S. 2011. Monoclonal antibodies to snakehead, Channa striata immunoglobulins: Detection and quantification of immunoglobulin-positive cells in blood and lymphoid organs. Fish. Shellfish Immunol., 30: 569575. DOI: $10.1016 /$ j.fsi.2010.12.004.

Sood, N., Chaudhary, D. K., Singh, A. and Rathore, G. 2012. Monoclonal antibody to serum immunoglobulins of Clarias batrachus and its application in immunoassays. Gene, 511: 411-419. https://doi.org/10.1016/j.gene.2012.09.044.

Suresh, B. P. P., Shankar, K. M., Honnananda, B. R., Vijaya, H. V., Shama, K. P., Suryanarayana, V. V. S. and Dechamma, H. J. 2008. Isolation and characterization of immunoglobulin of the Indian major carp rohu Labeo rohita (Ham.). Fish Shellfish Immunol., 24: 779-783. doi: 10.1016/j. fsi.2008.01.013.

Suresh, B. P., Shankar, K. M., Honnananda, B. R. and Abhiman, P. B. 2014. Monoclonal antibody-based immunodot for evaluating serum immunoglobulin levels in rohu (Labeo rohita). Aquac. Int., 22: 1451-1456.

Swain, T., Mohanty, J. and Sahu, A. K. 2004. One step purification and partial characterisation of serum immunoglobulin from Asiatic catfish (Clarias batrachus L.). Fish Shellfish Immunol., 17: 397-401. doi: 10.1016/j.fsi.2004.04.005.

Tang, X., Zhan, W., Sheng, X. and Chi, H. 2010. Immune response of Japanese flounder Paralichthys olivaceus to outer membrane protein of Edwardsiella tarda. Fish Shellfish Immunol., 28: 333-343. doi: 10.1016/j.fsi.2009.11.015.

Uchida, D., Hirose, H., Chang, P. K., Aranishi, F., Hirayabu, E., Mano, N., Mitsuya, T., Prayitno, S. B. and Natori, M. 2000. Characterisation of Japanese eel immunoglobulin $\mathrm{M}$ and its level in serum. Comp. Biochem. Physiol., 127B: 525-532. doi: 10.1016/s0305-0491(00)00290-x. 
Vesely, T., Reschova, S., Pokorova, D., Hulova, J. and Nevorankova, Z. 2006. Production of monoclonal antibodies against Ig heavy chain in common carp, (Cyprinus carpio L.). Vet. Med., 51: 296-302.

Watts, M., Munday, B. L. and Burke, C. M. 2001. Isolation and partial characterization of immunoglobulin from southern blue fin tuna Thunnus maccoyii Castelnau. Fish Shellfish Immunol., 11: 491-503. doi: 10.1006/fsim.2000.0329.

Wu, R., Shena, J., Lai, X., He, T. and Li, Y. 2020. Development of monoclonal antibodies against serum immunoglobulins from gibel carp (Carassius auratus gibelio) and their applications in serodiagnosis of inapparent infection and evaluation of vaccination strategies. Fish Shellfish Immunol., 96: 69-77.

Xu, G., Sheng, X., Xing, J. and Zhan, W. 2011. Effect of temperature on immune response of Japanese flounder (Paralichthys olivaceus) to inactivated lymphocystis disease virus (LCDV). Fish Shellfish Immunol., 30: 525-531. doi: 10.1016/j.fsi.2010.11.026.

Yanga, S., Tang, X., Sheng, X., Xing, J. and Zhan, W. 2018. Development of monoclonal antibodies against IgM of seabass (Lateolabrax japonicus) and analysis of phagocytosis by mIgM+lymphocytes. Fish Shellfish Immunol., 78: 372-382. doi: 10.1016/j.fsi.2018.04.042.

Zhan, W., Liu, H., Xing, J., Sheng, X. and Tang, X. 2009. Variation in the immunoglobulin levels in turbot (Scophthalmus maximus) after vaccination with Streptococcus iniae. Chin. J. Oceanol. Limnol., 27: 536-542.

Zilberg, D. and Klesius, H. 1997. Quantification of immunoglobulin in the serum and mucus of channel catfish at different ages and following infection with Edwardsiella ictaluri. Vet. Immunol. Immunopathol., 58: 171-180. doi: 10.1016/s0165-2427(97)00033-0. 